\title{
Sosialisasi Peningkatan Pengetahuan Remaja Karang Taruna Desa Tamansari Kecamatan Gunungsari Terhadap Organisasi Dan Sistem Pertandingan Olahraga
}

\author{
Nune Wire Panji Sakti ${ }^{1}$, Elya Wibawa $S^{2}$, Sukarman ${ }^{3}$. \\ Program Studi Pendidikan Olahraga Dan Kesehatan \\ Universitas Pendidikan Mandalika \\ Email: nunewire90@gmail.com
}

\begin{abstract}
Abstrak; Manusia pada hakekatnya mempunyai kesanggupan yang terbatas, baik kemampuan fisik maupun kemampuan psikis. Karena keterbatasan itulah maka manusia sering mengalami kegagalan demi kegagalan. Manusia dalam kelangsungan hidup, saling membutuhkan satu sama lain. Manusia yang ingin mencapai tujuan tertentu, maka manusia tersebut harus bekerja sama. Sehingga dengan kata lain, manusia harus bertindak dengan berorganisasi, agar tujuan tersebut dapat dicapai dengan baik. Pada tingkat kehidupan bermasyarakat yang modern, dan dengan majunya ilmu pengetahuan, daya tangkap dan kreasi manusia semakin giat, maka dari itu masyarakat mulai bertindak secara sadar di dalam melakukan tindakan-tindakan menurut tata cara organisasi.Organisasi merupakan suatu wadah yang di dalamnya terdiri dari orang orang, sarana, biaya dan tujuan yang terorganisir dengan baik untuk mencapai suatu tujuan. Demikian halnya dengan organisasi pertandingan, khususnya di dalam pertandingan olahraga, diperlukan suatu organisasi yang dapat menghimpun orang-orang untuk dapat melaksanakan suatu pertandingan olahraga dengan baik. Sehingga tujuan organisasi yang terhimpun dalam suatu kepanitiaan olahraga dapat tercapai dengan lancar dan tepat waktu. FPOK sebagai satu-satunya fakultas dilingkungan UNDIKMA Mataram yang telah menunjukkan perkembangannya yang terus maju dan inovatif dalam bidang olahraga dari sejak awal berdiri hingga sekarang, sehingga saya selaku akademisi yang memegang mata kuliah organisasi dan sistem pertandingan tahun ajaran 2020/2021. Ingin memberikan perhatian lebih dalam mengelola sistem pertandingan di lingkungan masyarakat khususnya remaja Karang Taruna Desa Tamansari. Sehingga dalam melakukan sistem pertandingan lancar, tepat sesuai peraturan, sehingga bagan tidak tumpang tindih dan serta tepat waktu dalam menyelesaikan pertandingan.
\end{abstract}

Kata Kunci: Peningkatan pengetahuan, Remaja Karang Taruna, Organisasi dan Sistem Pertandingan, Olahraga

\section{PENDAHULUAN}

Manusia pada hakekatnya mempunyai kesanggupan yang terbatas, baik kemampuan fisik maupun kemampuan psikis. Karena keterbatasan itulah maka manusia sering mengalami kegagalan demi kegagalan. Manusia dalam kelangsungan hidup, saling membutuhkan satu sama lain. Manusia yang ingin mencapai tujuan tertentu, maka manusia tersebut harus bekerja sama. Sehingga dengan kata lain, manusia harus bertindak dengan berorganisasi, agar tujuan tersebut dapat dicapai dengan baik. Pada tingkat kehidupan bermasyarakat yang modern, dan dengan majunya ilmu pengetahuan, daya tangkap dan kreasi manusia semakin giat, maka dari itu masyarakat mulai bertindak secara sadar di dalam melakukan tindakan-tindakan menurut tata cara organisasi. Organisasi merupakan suatu wadah yang di dalamnya terdiri dari orang orang, sarana, biaya dan tujuan yang terorganisir dengan baik untuk mencapai suatu tujuan.Hal ini perlu dilakukan untuk dapat mengatasi pemborosan tenaga, uang, materiil, untuk mencegah sekecil mungkin kesalahankesalahan dan lain-lain. Tindakan-tindakan tersebut adalah untukpencapaian hasil yang maksimal dengan cara yang efisien dan efektif.

Demikian halnya dengan organisasi pertandingan, khususnya di dalam pertandingan olahraga, diperlukan suatu 
organisasi yang dapat menghimpun orangorang untuk dapat melaksanakan suatu pertandingan olahraga dengan baik. Sehingga tujuan organisasi yang terhimpun dalam suatu kepanitiaan olahraga dapat tercapai dengan lancar dan tepat waktu.Problem atau masalah ini saya temukan, ketika saya selalu di undang sebagai saksi dan akademisi dalam kegiatan teknikal meeting pencabutan lot bagan pertandingan di setiap sekolah yang mengadakan pertandingan baik di Lombok Barat dan Mataram Kota, banyak sekali terjadi kekeliruan yang mendasar, contohnya pada pembagian bagan pertandingan, banyak peserta mengatakan tidak adil dan posisi bye di taruh tidak sesuai dengan aturan organisasi dan sistem pertandingan yang tepat. Kepanitian dalam lingkungan sekolah, juga selalu menjadi problem, ketika berjalan di pertengahan mendekati hari " $\mathrm{H}$ " pertandingan panitia, mengalami selisih dan kadang terjadi perpecahan.

Berdasarkan problem itulah, FIKKM sebagai satu-satunya fakultas dilingkungan UNDIKMA Mataram yang telah menunjukkan perkembangannya yang terus maju dan inovatif dalam bidang olahraga dari sejak awal berdiri hingga sekarang, sehingga saya selaku akademisi yang memegang mata kuliah organisasi dan sistem pertandingan tahun ajaran 2020/2021. Ingin memberikan perhatian lebih dalam mengelola sistem pertandingan di lingkungan masyarakatk hususnya remaja Karang Taruna Desa Tamansari . Kegiatan sosialisasi organisasi dan sistem pertandingan sangat penting di ajarkan pada sekolah yang pada zaman modern ini di tuntut untuk melakukan perkembangan dunia olahraga oleh pemerintah daerah, terlihat dari turnamenturnamen yang sering diadakan sekolah-sekolah. Sehingga dalam melakukan pertandingan sekolah tersebut memiliki sistem yang benar, sehingga dalam melakukan kegiatan lancar, tepat sesuai peraturan bagan tidak tumpang tindih, adil dan tepat waktu dalam menyelesaikan pertandingan.

Target dari Program Pengabdian Masyarakat Internal "Sosialisasi Peningkatan Pengetahuan remaja Karang Taruna Desa Tamansari Kecamatan Gunungsari Terhadap Organisasi dan Sistem Pertandingan" adalah memberikan pengetahuan awal mengenai pengertian organisasi, ciri-ciri organisasi, bentuk-bentuk organisasi, pengertian pertandingan, jenis-jenis pertandingan, bentukbentuk pertandingan, pengertian perlombaan, dan jenis-jenis perlombaan bagi siswa/ sekolah yang ingin mengadakan turnamen/ pertandingan olahraga sehingga sistem yang di jalankan terarah, bagan pertandingan jelas dan adil serta waktu pelaksanaan dan penutupan sesuai target yang di tentukan.

Hasil yang ingin dicapai dari kegiatan atau program Pengabdian Masyarakat Internal ini adalah sebesar-besarnya untuk kepentingan remaja Karang Taruna Desa Tamansari sukses dalam melakukan kegiatan dan mengenalkan kualitas akademisi FIKKM UNDIKMA Mataram sehinggapara akademisi UNDIKMA Mataram khususnya Program Studi Pendidikan Olahraga dan Kesehatan Fakultas Ilmu Keolahragaan dan Kesehatan Masyarakat, bisa menjadi pelopor pengembangan dan pembangunan dunia olahraga di NTB yaitu dalam membantu remaja dalam pelaksanaan kegiatan pertandingan dan untuk menambah pengetahuan secara luas tentang organisasi dan sistem pertandingan.

\section{METODE PELAKSANAAN \\ Persiapan Kegiatan}

Persiapan Kegiatan yang dilakukan terdiri dari:

1. Mekanisme sebelum pelaksanaan kegiatan Sebelum terjun ke lapangan, maka perlu dilakukan beberapa hal sebagai bentuk persiapan, antara lain:

a) Melakukan verifikasi instansi yaitu Karang Taruna Desa Tamansari tempat diadakan pengabdian masyarakat ini sesuai dengaan prosedur yang berlaku di Lembaga Penelitian dan Pengabdian kepada Masyarakat di UNDIKMA.

b) Melakukan pendataan kepada peserta program terkait dengan kegiatan yang akan dilaksanakan.

c) Mempersiapkan spanduk dan sertifikat bagi peserta dan panitia.

2. Materi sosialisasi peningkatan pengetahuan terhadap organisasi dan sistem pertandingan bagi remaja Karang 
Taruna Desa Tamansari disampaikan oleh TIM Ketua yaitu Nune Wire Panji Sakti, M.Pd.

\section{Pelaksanaan Program}

Adapun tahapan-tahapan pelaksanaan program didesain sebagai berikut:

1. Mempersiapkan tim yang akan terjun langsung ke lapangan yaitu 1 dosen sebagai pemateri sedangkan 4 dosen lainnya terbagi atas 2 Dosen bertanggung jawab pada acara dan 2 Dosen lainnya bertanggung jawab pada peralatan dan perlengkapan.

2. Memberikan materi berupa sosialisasi peningkatan pengetahuan terhadap organisasi dan sistem pertandingan bagi remaja Karang Taruna Desa Tamansari dengan durasi 90 menit, kemudian dilanjutkan dengan sesi tanya jawab antara peserta dan pemateri.

\section{Rancangan Pelaksanaan Pengabdian Masyarakat}

Tabel 1. Rancangan Pelaksanaan Pengabdian

\begin{tabular}{|c|c|c|c|}
\hline Rancangan Kegiatan & Waktu & Pelaksanaan & Pem: \\
\hline $\begin{array}{l}1 \text { Penyampaian materi tentang } \\
\text { pentingnya pengetahuan } \\
\text { terhadap organisasi dan sistem } \\
\text { pertandingan } \\
\text { a) Sejarah dan pengertian } \\
\text { organisasi, } \\
\text { b) Bentuk organisasi, } \\
\text { c) Manfaat organisasi, } \\
\text { d) Manajemen organisasi, } \\
\text { c) jenis-jenis pertandingan, } \\
\text { f) Struktur organisasi dan tugas } \\
\text { serta tanggung jawab panitia, } \\
\text { g) pengertian system kompetisi } \\
\text { b) System kompetisi penuh, } \\
\text { setengah kompetisi } \\
\text { i) jenis-jenis perlombaan } \\
\text { j) pengurutan peringkat } \\
\text { k) Laporan akhir dan laporan } \\
\text { keuangan }\end{array}$ & $\begin{array}{c}10.00-11.30 \\
\& \\
15.00-17.00\end{array}$ & $\begin{array}{l}\text { Team : } \\
\text { Nune Wire Panji } \\
\text { Sakti, M. Pd } \\
\text { Dr. Elya Wibawa } \\
\text { S, M. Pd } \\
\text { Sukarman, M. Ag }\end{array}$ & $\begin{array}{l}\text { Nune Wire I } \\
\text { M. Pd }\end{array}$ \\
\hline
\end{tabular}

\subsection{Jadwal Kegiatan Program}

Kegiatan pengabdian masyarakat ini dilaksanakan pada bulan Desember tahun 2020 di AULA Desa Tamansari dengan peserta 50 orang, yang masing-masing Remaja Karang Taruna Desa Tamansari berjumlah 25 orang siswa dan Undangan Karang Taruna di Kecamatan Gunungsari berjumlah 25 orang, pada saat mengadenkan kejuaraan di Turnamen Desa.

\section{HASIL KEGIATAN PENGABDIAN Gambaran Umum Lokasi Kegiatan Masyarakat}

Remaja Karang Taruna Desa Tamansari merupakan salah satu Desa yang berada di Kecamatan Gunungsari Kabupaten Lombok Barat Provinsi Nusa Tenggara Barat. Sejak berdiri sampai sekarang ini Karang Taruna tersebut yang di komandoi oleh Rahmat, mereka masing-masing sangat ingin menyelenggarakan pertandingan atau turnamen Futsal di Desa tersebut, atas keinginan inilah tim pengabdian UNDIKMA melakukan kegiatan pengabdian masyarakat dengan tema "Sosialisasi Peningkatan Pengetahuan remaja Karang Taruna Desa Tamansari Kecamatan Gunungsari Terhadap Organisasi dan Sistem Pertandingan". Pemilihan lokasi tersebut berdasarkan dari hasil observasi awal yang menunjukkan adanya remaja yang tergabung dalam Karang Taruna tersebut yang ingin menyelenggarakan pertandingan futsal sebagai agenda tahunan yang akan di selenggarakan di ULTAH Desa tersebut.

\section{Gambaran Umum Peserta Pengabdian Masyarakat}

Kegiatan pengabdian ini dihadiri oleh total 50 peserta yaitu anggota Karang Taruna Desa Tamansari dan perwakilan Remaja Karang Taruna di Kecamatan Gunungsari.

\section{Pelaksanaan Pengabdian Masyarakat}

Sebagaimana yang telah diuraikan pada sub-sub tema sebelumnya, bahwa kegiatan pengabdian masyarakat ini terlahir dari hasil observasi awal pada anggota Karang Taruna tersebut yang setiap melakukan kegiatan Perlombaan Maulid Nabi SAW, mereka masing-masing berkeinginan besar membuat agenda tahunan yaitu membuat pertandingan atau turnamen futsal skala kabupaten maupun Provinsi nantinya. Karena perlu di ketahui Desa Tamansari Kecamatan Gunungsari tersebut belum pernah menyelenggaran turnamen futsal skala kabupaten maupun provinsi sama sekali.

Keinginan atau mimpi besar anggota Karang Taruna tersebutlah maka FIKKM UNDIKMA hadir memberikan solusi agar nantinya bukan turnamen futsal yang mereka bisa selenggarakan dengan skala kabupaten maupun provinsi nantinya. Karena dengan adanya turnamen besar skala kabupaten 
maupun provinsilah remaja mereka bisa dikenal di kalangan masyarakat. Hal tersebut sangat penting dilakukan oleh Desa secara mandiri, dimana dengan cara itu dapat mendidik remaja Karang Taruna dalam segala hal, yang pertama remaja dapat mengembangkan potensinya dalam menjadi EO pertandingan, ke dua remaja dapat di ajarkan mandiri dalam berusaha untuk bisa sukses dalam tujuannya, ke tiga remaja bisa bersosialisasi dan memiliki perencanaan dengan baik, dan selanjutnya bisa di ajarkan cara bekerjasama dalam berorganisasi dengan baik sehingga bisa mencapai tujuannya dengan sukses, dan yang paling penting remaja tersebut bisa membuat laporan akhir serta laporan keuangan untuk pertanggung jawaban dalam melaksanakan berbagai macam kegiatan turnamen.

Selanjutnya, kegiatan pengabdian masyarakat ini dilaksanakan pada hari Senin 10 Agustus 202 di AULA Desa Tamansari dengan 1 orang pemateri. Kegiatan dilakukan dari jam 10.00 pagi sampai jam 11,30 siang, lokasi di Desa Tamansari dilakukan dari jam 15.00 siang sampai jam 17,00 sore. Kegiatan ini dilakukan dengan metode penyampaian materi dan tanya jawab.

Tahapan kegiatan akhir, perwakilan inti dalam bidang keolahragaan di Karang Taruna Desa Tamansari mereka masing-masing langsung diberikan pengalaman mengadakan pertandingan oleh FIKKM UNDIKMA yang insyaallah akan dilaksakan tahun 2021 dengan tema kegiatan pertandingan Dekan Futsal FIKKM UNDIKMA tahun 2021 yang di lakukan persiapan dari bulan Agustus sampai pelaksanaan turnamen yaitu 20 Oktober hingga 26 Oktober 2020 bertempat di lapangan futsal Gelanggang Pemuda Olahraga Kecamatan Gunungsari Kabupaten Lombok Barat prov. NTB. Hasil menunjukkan semua peserta merasakan mendapatkan pengetahuan baru yang berhubungan dengan Organisasi dan sistem pertandingan, baik pengalaman administrasi hingga pengalaman lapangannya dan mereka mengharapkan bisa melakukan agenda tersebut pada saat ULTAH Desa mereka masing-masing.

\section{SIMPULAN KEGIATAN}

Abdi Masyarakat
Semoga dengan adanya kegiatan sosialisasi ini tidak hanya Desa besar yang ada di Mataram bisa melakukan atau menyelenggarakan turnamen melainkan Desa di kabupaten, karena penting sebagai perkenalan remaja mereka dan sebagai menambah pengetahuan remaja selain di bidang akademik. Karena skill non akademik seperti ini juga perlu bagi remaja untuk melatih sikap kerjasama dan mengenal lingkungan di luar. Semoga lahirlah EO pertandingan yang bisa menyelenggarakan turnamen besar bertaraf Nasional dan Internasional di Nusa Tenggara Barat.

\section{DAFTAR PUSTAKA}

Aip Sarifudin, Organisasi dan Tatalaksana Penyelenggaraan Pertandingan Olahraga, untuk SPG, SGO, SGPLB, Departemen Pendidikan dan Kebudayaan, Jakarta, 1981.

Edward. F, etal, The Organization and Administration of Physical Education, New York, Appleton-Century-Crofts, Inc., 1978.

Husdarta JS. Pendidikan Olahraga dan Kesehatan, Bahan Perkuliahan MKDU, Olahraga dan Kesehatan IKIP Bandung, 1988.

KONI Pusat, (2017), Susunan Pengurus KONI Pusat, KORWIL, KONI Induk Organisasi Cabang Olahraga dan Badan Fungsional. 